\title{
Does dietary n-3 highly unsaturated fatty acids level influence the European sea bass (Dicentrachus labrax) capacity to adapt to a high temperature?
}

\author{
J. Person-Le Ruyet ${ }^{a}$, A. Skalli ${ }^{b}$, B. Dulau ${ }^{a}$, N. Le Bayon ${ }^{a}$, H. Le Delliou ${ }^{a}$ and J.H. Robin ${ }^{a}$ \\ a Unité mixte Nutrition, Aquaculture, Génomique Inra-Ifremer-Bordeaux I, Laboratoire Adaptation Reproduction \\ Nutrition des Poissons, Ifremer, Centre de Brest, BP 70, 29280 Plouzané, France \\ ${ }^{\mathrm{b}}$ Departamento Biología Animal y Ecología, Facultad de Ciencias Universidad de Granada, Spain \\ *: Corresponding author : Jeannine.Person@ifremer.fr
}

\begin{abstract}
Triplicate groups of European sea bass juveniles $(60 \mathrm{~g})$ were fed for 84 days two experimental diets containing either vegetable or marine oil $(0.4$ and $2.2 \% n-3$ highly unsaturated fatty acid [n-3 HUFA] dry matter in LD and HD, respectively) and held at 22 or $29^{\circ} \mathrm{C}$ (LD-22, LD-29, HD-22 and HD-29 groups). Significant differences in mass gain between the two diets and temperatures were observed from day 28 onwards, and on day 84 , weight was $18 \%$ higher in the HD-29 group than in the LD-22 group (the highest and lowest values, respectively). Over the 84-day period, SGR was significantly affected both by temperatures and diets $(\mathrm{P}=6 \times 10-4$ and $2 \times 10-4$ respectively), averaging 1.01 and 1.07 in the HD-22 and HD-29 groups compared to 0.92 and 1.0 in the LD-22 and LD-29 groups. Differences in growth rate between the experimental conditions were mainly explained by differences in feed intake $(\mathrm{FI})$. $\mathrm{FI}$ was more affected by temperature than by diets (in fish fed HD, it was $1.7 \%$ day -1 at $29^{\circ} \mathrm{C}$ and $1.4 \%$ day- 1 at $22{ }^{\circ} \mathrm{C}$, and $1.7 \%$ day- 1 and $1.3 \%$ day-1, respectively, with LD). Feed conversion ratio (FCR) was significantly affected by temperature and diets; days $0-84$ FCR was on HD and LD 1.6 and 1.7 at $29^{\circ} \mathrm{C}$ and $1.4-1.5$ at $22{ }^{\circ} \mathrm{C}$. Considering growth and feeding parameters, no interaction between dietary concentration in n-3 HUFA and temperatures were observed. In acclimated fish, MO2 on routine metabolism was the highest at HD-29 (396 mg O2 kg-1 $\mathrm{h}-1$ ) as it was dependent on FI. There was no major difference in fish whole body composition, and protein retention was more affected by temperature than by diets. Diets and temperature affected polar lipid fatty acid content, without interaction; n-3 HUFAs were lower at $29^{\circ} \mathrm{C}$ than at $22^{\circ} \mathrm{C}$. Fatty acids of total and neutral lipids (NL) were mainly affected by dietary fatty acids, while some low but significant influences of temperature were observed. Interactions between the two studied factors concerned particularly n-3 HUFAs content, lower at 29 than at $22{ }^{\circ} \mathrm{C}$ only in fish fed vegetable oil (LD). This study demonstrated that in high-quality sea bass juveniles, a 3-month deficiency in dietary n-3 HUFA did not drastically impair fish capacity to adapt to a high temperature, $29^{\circ} \mathrm{C}$.
\end{abstract}

Keywords: European sea bass; n-3 HUFA; Temperature; Growth; Fatty acid composition; Oxygen consumption 


\section{Introduction}

Lipids play an important role in fish nutrition for the provision of body energy and essential fatty acids (Ackman, 1995; Parpoura and Alexis, 2001; Sargent et al., 2002). A considerable amount of research has been focused on n-3 highly unsaturated fatty acid (n-3 HUFA) requirement of marine fish and specifically on eicosapentaeoic acid (EPA; 20:5n-3) and docosahexaenoic acid (DHA; 22:6n-3). There is also an increasing interest in the role of fatty acids in metabolism as the use of vegetable proteins and oils in fish diets will reduce n-3 HUFA contents and change the fatty acid balance in fish tissues (Bell et al., 1996; Sargent et al., 2002; Tocher, 2003). Problems associated with animal proteins make vegetable sources the most promising candidates as substitutes for marine protein and lipids (Lodemel et al., 2001; Ringo et al., 2002; Kaushik et al., 2004). Partial substitution of fish oil by vegetable oil has been demonstrated possible in salmonids (Rosenlund et al., 2001; Caballero et al., 2002; Grisdale-Helland et al., 2002) and in most farmed marine fish species (Kalogeropoulos et al., 1992; Alexis, 1997; Yildiz and Sener, 1997; Izquierdo et al., 2003; Regost et al., 2003). Nevertheless, reduced growth and changes in flesh quality due to a n-3 HUFA deficiency or an inadequate EPA-DHA ratio were observed when both vegetable oils and protein sources were used (Skalli and Robin, 2004).

As HUFA are involved in many physiological processes (Sargent et al., 2002; Tocher, 2003), fish n-3 HUFA requirements could be modulated by environmental factors (temperature, salinity). For example, it has been shown that in juvenile European sea bass held at $22^{\circ} \mathrm{C}$, the dietary n-3 HUFA requirement was $0.7 \%$ DM (Skalli and Robin, 2004). Fish capacity to adapt to any sustained or acute environmental stress (temperature changes, 
oxygen depletion, ammonia discharge) may be affected by fish nutritional status (Salte et al., 1988). Mckenzie (2001) has shown that a dietary supplementation in n-3 HUFA increased the tolerance to hypoxic conditions of the European eel and of the Adriatic sturgeon. The role of n-3 HUFA in the structural flexibility of biological membranes is still poorly documented in fish living at different temperatures (Hazel, 1993; Farkas et al., 1994). In marine fish, the available data concerning the effects of temperature on tissue lipid composition are related to low temperature (Ventrella et al., 1993; Staurnes et al., 1994), but the effects of high temperature on nutritional requirement are poorly documented. It has been shown in juvenile sea bass of a Mediterranean population that temperature for maximum growth was $26^{\circ} \mathrm{C}$ and the upper temperature for growth was close to $29^{\circ} \mathrm{C}$ (Person-Le Ruyet et al., 2004). To our knowledge, the long-term combined effects of n-3 HUFA and temperature on fish growth have received little attention.

The aim of this study was to assess the effects of n-3 HUFA and temperature on growth performances and body composition of sea bass from a Mediterranean population. For this purpose, feed intake, growth, metabolism and body composition were examined in juveniles fed two dietary n-3 HUFA contents ( 0.4 and $2.2 \%$; less or above minimal requirement) and held at two stabilized temperatures $\left(22\right.$ and $29^{\circ} \mathrm{C} ; 3^{\circ} \mathrm{C}$ above or below the temperature for maximum growth). 


\section{Materials and methods}

\subsection{Fish and rearing conditions}

The experiment was carried out using 4-month old hatchery reared juvenile European sea bass (Dicentrachus labrax) previously held for 2 months in $4-\mathrm{m}^{2}$ tanks supplied with running seawater $\left(34-34.5 \%\right.$, $22^{\circ} \mathrm{C}$, oxygen $90-95 \%$ saturation) and fed a commercial dry pellet (Ecolife $15^{\circledR}$, crude protein $45 \%$ and crude fat $16 \%$ ) distributed $8 \mathrm{~h}$ per day using belt feeders. The photoperiod was maintained at $18 \mathrm{~L}: 6 \mathrm{D}$ cycle and maximum light intensity was $2 \mathrm{~W} \mathrm{~m}^{-2}$ at the water surface.

For the experiment, 1500 fish (previously individually weighed and sorted) were randomly distributed among the 12 experimental tanks, $1-\mathrm{m}^{2}$ tanks with an effective volume of 4501 , covered with a bag with an observation window to avoid visual stress. They were adapted to the rearing and feeding conditions of the experiment for 21 days. They were held in water at $22^{\circ} \mathrm{C}$ with an $\mathrm{O}_{2}$-concentration of $7.8 \mathrm{mg}^{-1}$ [105\% saturation prior to fish feeding, using an oxygen supplementation device (Person-Le Ruyet et al., 2002)]. Water exchange rate was $165 \% \mathrm{~h}^{-1}$. The fish were hand-fed to visual satiation at 0900 and $1400 \mathrm{~h}$; any uneaten feed was collected in a waste trap fitted to the outflow, and feed intake was calculated for each meal as feed provided minus feed waste. 


\subsection{Experimental design}

The 84-day experiment was carried out using triplicate groups of 84 fish each, held at 22 or $29^{\circ} \mathrm{C}$. On day 0 , the initial mass per tank was assessed by weighing all fish in the tank. The fish were fasted for $24 \mathrm{~h}$ and anaesthetised in a solution of ethylene-glycolmonophenyl-ether $(0.5 \%)$ before weighing. Mean fish weight was ca $59 \mathrm{~g}$ and stocking density was ca $13 \mathrm{~kg} \mathrm{~m}^{-3}$ (Table 1). From day 0 onwards, six tanks were maintained at $22^{\circ} \mathrm{C}$, and in the other six tanks, temperature was gradually increased to $29^{\circ} \mathrm{C}$ by $3^{\circ} \mathrm{C}$ day ${ }^{-1}$ and maintained constant until the end of the experiment. The fish were fed the two experimental diets formulated to be isoproteic and isolipidic, $50 \%$ crude protein and $16 \%$ crude lipid content and to contain $2.2 \%$ or $0.4 \%$ n-3 HUFA (HD and LD diets, respectively). The two diets differed only by the oil added. The major protein source was of vegetable origin (lupin meal) as a way to obtain the desired n-3 HUFA level in LD. In HD cod liver oil was added to increase n-3 HUFA content while in LD it was totally replaced by a vegetable oil source, rapeseed oil containing no HUFAs. Ingredient and chemical composition of the two diets are reported in Table 2, and fatty acid (FA) composition in Table 3. 
Table 1. Experimental conditions tested in the 84-day experiment and data related to sea bass and to water quality.

\begin{tabular}{lllll}
\hline Experimental conditions & HD-22 & HD-29 & LD-22 & LD-29 \\
\hline Temperature $\left({ }^{\circ} \mathrm{C}\right)$ & $21.7 \pm 0.05$ & $28.7 \pm 0.15$ & $21.7 \pm 0.05$ & $28.7 \pm 0.15$ \\
Day 0 fish number & 300 & 300 & 300 & 300 \\
Day 0 fish weight $(\mathrm{g}) *$ & $58.3 \pm 0.1$ & $59.3 \pm 0.3$ & $58.3 \pm 0.4$ & $59.3 \pm 0.7$ \\
Day 0 weight CV (\%) & $10.10 \pm 0.36$ & $9.40 \pm 0.06$ & $9.0 \pm 0.050 .36$ & $9.05 \pm 0.02$ \\
Day 0 stocking density $\left(\mathrm{kg} \mathrm{m}^{-3}\right)$ & $13.0 \pm 0.03$ & $13.2 \pm 0.07$ & $13.1 \pm 0.11$ & $13.2 \pm 0.19$ \\
Day 84 fish number & 240 & 240 & 240 & 240 \\
Day 84 fish weight $(\mathrm{g}) *$ & $138.0 \pm 1.9$ & $150.0 \pm 2.8$ & $127.0 \pm 1.4$ & $141.5 \pm 1.6$ \\
Day 84 weight CV (\%) & $14.70 \pm 0.98$ & $15.07 \pm 0.53$ & $13.49 \pm 1.37$ & $15.99 \pm 0.35$ \\
Day 84 stocking density $(\mathrm{kg} \mathrm{m}$ & $24.5 \pm 0.40$ & $26.7 \pm 0.62$ & $22.6 \pm 0.31$ & $25.2 \pm 0.36$ \\
$\mathrm{O}_{2}$-conc. $(\%$ saturation) & $110 \pm 0.4$ & $115 \pm 0.2$ & $113 \pm 0.7$ & $115 \pm 0.3$ \\
$\mathrm{O}_{2}$-conc. $\left(\mathrm{mg} \mathrm{l}^{-1}\right)$ & 8.0 & 7.5 & 8.2 & 7.5 \\
Salinity & $34.8 \pm 0.1$ & $35.0 \pm 0.1$ & $34.8 \pm 0.1$ & $35.0 \pm 0.1$ \\
PH & $8.02 \pm 0.01$ & $7.91 \pm 0.01$ & $8.02 \pm 0.01$ & $7.88 \pm 0.01$ \\
TAN (mg 1 ${ }^{-1}$ ) & $0.21 \pm 0.03$ & $0.27 \pm 0.03$ & $0.21 \pm 0.03$ & $0.30 \pm 0.03$ \\
\hline
\end{tabular}

Means are given with SE; fish weight, weight $\mathrm{CV}$ and stocking density, $\mathrm{n}=3 ; \mathrm{O}_{2}$-concentrations, $\mathrm{n}=105$; $\mathrm{pH}$ and Total Ammonia Nitrogen (TAN), $\mathrm{n}=12$; salinity, $\mathrm{n}=19 ; *$ statistical analysis results reported in Fig. 1. 
Table 2. Formulation ( $\left(100 \mathrm{~g}^{-1}\right)$ and chemical composition (\% DM) of the experimental diets.

\begin{tabular}{lcc}
\hline Ingredients $^{\mathrm{a}}\left(\mathrm{g} 100 \mathrm{~g}^{-1}\right)$ & \multicolumn{2}{c}{ Experimental diets } \\
\cline { 2 - 3 } & HD & LD \\
\hline Fish meal Norse LT 94 & 20.0 & 20.0 \\
Fish hydrolysate CPSP-90 & 8.0 & 8.0 \\
Lupin meal & 50.0 & 50.0 \\
Corn gluten & 7.0 & 7.0 \\
Vitamin mixture $^{\mathrm{b}}$ & 1.0 & 1.0 \\
Mineral mixture $^{\mathrm{c}}$ & 1.0 & 1.0 \\
Pregelatinized starch & 4.8 & 4.8 \\
D-L-Methionine & 0.2 & 0.2 \\
Marine fish oil (cod liver oil) & 8.0 & \\
Vegetable oil (rapeseed oil) & & 8.0 \\
Chemical composition (\% DM) & & \\
Dry matter & & 93.0 \\
Crude protein & 93.5 & 51.2 \\
Crude fat & 51.4 & 16.1 \\
Ash & 16.1 & 4.2 \\
n-3 HUFA & 4.2 & 0.4 \\
\hline
\end{tabular}

a Sources: fish meal and cod liver oil: La Lorientaise ${ }^{\circledR}$ (Lorient, France); fish protein hydrolysates: Sopropêche ${ }^{\circledR}$ (Boulogne sur mer, France); rapessed oil: Associated oil Packers, France.

${ }^{\mathrm{b}}$ Vitamin mixture $\left(\mathrm{g} \mathrm{kg}^{-1}\right.$ vitamin mix): retinyl acetate, 1; cholecalciferol, 2.5; DL- $\alpha$-to copheryl acetate, 5; menadione, 1; thiamin- $\mathrm{HCl}, 0.1$; riboflavin, 0.4; D-calcium panthothenate, 2; pyridoxine- $\mathrm{HCl}, 0.3$; cyanocobalamin, 1 ; niacin, 1; choline, 200; ascorbic acid (ascorbyl polyphosphate), 5; folic acid, 0.1; D-biotin, 1; meso-inositol, 30. All ingredients were diluted with $\alpha$-cellulose.

${ }^{\mathrm{c}}$ Mineral mixture (g kg${ }^{-1}$ mineral mix): KCl, 90; KI, 0.04; $\mathrm{CaHPO}_{4} \cdot 2 \mathrm{H}_{2} \mathrm{O}, 500 ; \mathrm{NaCl}, 40$; $\mathrm{CuSO}_{4} \cdot 5 \mathrm{H}_{2} \mathrm{O}, 3 ; \mathrm{ZnSO}_{4} \cdot 7 \mathrm{H}_{2} \mathrm{O}, 4 ; \mathrm{CoSO}_{4}, 0.02 ; \mathrm{FeSO}_{4} \cdot 7 \mathrm{H}_{2} \mathrm{O}, 20 ; \mathrm{MnSO}_{4} \cdot \mathrm{H}_{2} \mathrm{O}, 3 ; \mathrm{CaCO}_{3}$, $215 ; \mathrm{MgOH}, 124 ; \mathrm{Na}_{2} \mathrm{SeO}_{3}, 0.03 ; \mathrm{NaF}, 1$. 
Table 3. Composition of dietary fatty acids (in \% total fatty acid methyl esters).

\begin{tabular}{lcc}
\hline Fatty acids & \multicolumn{2}{c}{ Experimental diets } \\
\cline { 2 - 3 } & HD & LD \\
\hline Esaturates & 20.0 & 11.7 \\
$14: 0$ & 3.5 & 0.6 \\
$16: 0$ & 11.8 & 6.9 \\
$18: 0$ & 2.5 & 1.8 \\
$20: 0$ & 0.7 & 0.8 \\
$22: 0$ & 1.3 & 1.3 \\
$\sum$ monoenes & 47.8 & 58.6 \\
$16: 1 \mathrm{n}-7$ & 3.8 & 0.8 \\
$18: 1 \mathrm{n}-7$ & 2.6 & 2.6 \\
$18: 1 \mathrm{n}-9$ & 28.4 & 49.1 \\
$20: 1 \mathrm{n}-9$ & 6.0 & 3.4 \\
$22: 1 \mathrm{n}-9$ & 1.2 & 0.9 \\
$24: 1 \mathrm{n}-9$ & 0.3 & 0.2 \\
$20: 1 \mathrm{n}-11$ & 0.5 & 0.2 \\
$22: 1 \mathrm{n}-11$ & 4.4 & 1.2 \\
$\sum n-6$ & 10.5 & 18.1 \\
$18: 2 \mathrm{n}-6$ & 9.5 & 17.7 \\
$18: 3 \mathrm{n}-6$ & 0.1 & 0.0 \\
$20: 2 \mathrm{n}-6$ & 0.3 & 0.2 \\
$20: 3 \mathrm{n}-6$ & 0.1 & 0.0 \\
$20: 4 \mathrm{n}-6$ & 0.4 & 0.1 \\
$\sum n-3$ & 21.7 & 11.6 \\
$18: 3 \mathrm{n}-3$ & 4.3 & 7.9 \\
$\sum n-3$ HUFA & 14.9 & 3.2 \\
$20: 5 \mathrm{n}-3$ & 6.4 & 1.2 \\
$22: 5 \mathrm{n}-3$ & 1.3 & 0.1 \\
$22: 6 \mathrm{n}-3$ & 7.2 & 1.9 \\
\hline & &
\end{tabular}


Water $\mathrm{O}_{2}$-concentration was checked in outlet water once a day prior to feeding and adjusted as required by changing $\mathrm{O}_{2}$ injection to maintain $100-105 \%$ saturation. Total gas pressure was checked with a tensionometer $\left(300 \mathrm{C} \mathrm{Novatech}^{\circledR}\right)$ at the beginning and end of the experiment. Salinity $\left(\mathrm{WTV}^{\circledR}\right)$ and $\mathrm{pH}$ (Orion 901 fitted with a Fermprobe ${ }^{\circledR}$ electrode) were measured weekly and total ammonia nitrogen (TAN) was measured once a month (automatic colorimetric method as described in Dosdat et al. (1996)).

Six fish were randomly removed from each tank on days 7, 14, 28, 57 and 84 for analysis and weighed for mass estimation and comparison with fish remaining in each tank. As a result, stocking density was maintained below ca $27 \mathrm{~kg} \mathrm{~m}^{-3}$ and water quality was consistent (Table 1).

The digestibility of HL and LD was tested in triplicate groups of 60 fish (60 g) using chromic oxide as an inert tracer (1\% of DM diet). Fish were held in 6 cylindro-conical tanks (150 1) supplied with running water $\left(23^{\circ} \mathrm{C}, 35 \%\right.$ salinity, $141 \mathrm{~min}^{-1}$ water-flow rate) and fitted with a faeces-settling column adapted from Cho et al. (1982). Following a 3week period of acclimation to the rearing conditions, faecal samples (faeces plus residual water) were collected for two weeks, centrifuged $\left(3000 \mathrm{x} \mathrm{g}\right.$ at $6^{\circ} \mathrm{C}$ for $\left.20 \mathrm{~min}\right)$ and kept frozen at $-20^{\circ} \mathrm{C}$ pending analysis on freeze-dried pooled samples for chromic oxide, protein, fat and energy. 


\subsection{Parameters evaluated}

Growth was estimated by weighing all fish on days $0,14,28,57$ and 84. Specific growth rate $\left(\mathrm{SGR}, \%\right.$ day $\left.^{-1}\right)$ was calculated as: $100 \times\left(\ln \mathrm{w}_{\mathrm{f}}-\ln \mathrm{w}_{\mathrm{i}}\right) \mathrm{day}^{-1}$, where $\mathrm{w}_{\mathrm{i}}$ and $\mathrm{w}_{\mathrm{f}}$ are the initial and final mean body weights, respectively. The coefficient of variation for body weight within each tank $(\mathrm{CV}, \%)$ was calculated as: $100 \mathrm{x}$ standard deviation $\mathrm{x}$ mean body weight ${ }^{-1}$.

As some fish were regularly removed from the tanks, daily feed intake (FI) and apparent feed conversion ratio (FCR) were calculated taking into account the average mass for $\mathrm{t}_{1}-\mathrm{t}_{2}$ period, (day1-7, 8-14, 15-28, 29-57, 58-84) using the following expressions:

- FI: 100 x (mean daily mass of dry feed ingested, g x mean wet fish mass ${ }^{-1}, \mathrm{~g}$ ) where mean fish mass $=\left(\right.$ fish mass at $t_{2}+$ fish mass at $\left.t_{1}\right) 2^{-1}$ and fish mass $=$ mean body weight $\mathrm{x}$ fish number;

- FCR: dry feed ingested, $\mathrm{g} x$ fish mass gain ${ }^{-1}, \mathrm{~g}$.

FI and FCR over the 84-day period were estimated on the basis of the mean value of the 2week periods per tank.

Body composition of whole fish was determined on 3 samples per treatment of 4 fish each taken from 3 different tanks on day 0 and from each replicated tank on day 84 . Fish were ground and moisture content was determined on homogenates samples $(24 \mathrm{~h}$ at $105^{\circ} \mathrm{C}$ ) and subsequently freeze-dried and ground before further analyses. Chemical analyses of fish and feed were performed in triplicate for each sample according to AOAC methods (Association of Official Analytical Chemists, 1984): ash (7 h at $550^{\circ} \mathrm{C}$ ), crude fat 
(Folch et al., 1957), crude protein (Dumas method with an Elementary NA $2000^{\circledR}$, $\mathrm{N} \times 6.25$ ) and gross energy (IKA Adiabatic Calorimeter $\mathrm{C}_{4000 \mathrm{~A}^{\circledR}}$ ). Protein retention was calculated as: $100 \times\left(\right.$ fish protein gain, $\mathrm{g} \times$ feed protein intake $\left.{ }^{-1}, \mathrm{~g}\right)$, where protein intake $=$ feed ingested $\mathrm{x}$ feed protein concentration and, protein gain $=($ final mean fish mass $\mathrm{x}$ final fish protein concentration) - (initial mean fish mass $\mathrm{x}$ initial fish protein concentration). Chromic oxide in the diets and faecal samples was determined according to Bolin et al. (1952). ADCs of the two experimental diets were calculated as follows:

$\operatorname{ADC}(\%)=100-\left[100\left(\% \mathrm{Cr}_{2} \mathrm{O}_{3}\right.\right.$ in diet $\% \mathrm{x} \mathrm{Cr}_{2} \mathrm{O}_{3}$ in faeces $\left.{ }^{-1}\right) \times(\%$ nutrient or energy in faeces $\mathrm{x} \%$ nutrient or energy in $\left.\left.\operatorname{diet}^{-1}\right)\right]$.

The separation of neutral lipids and phospholipids in diets and fish samples was performed according to the procedure described by Juaneda and Rocquelin (1985). The total lipid extracts were fractionated on silica cartridges (Sep-Pack, Waters); neutral lipids were eluted by chloroform and phospholipids by methanol. Lipids were saponified with $2 \mathrm{M}$ $\mathrm{KOH}$ in methanol $\left(3 \mathrm{~min}\right.$ at $\left.90^{\circ} \mathrm{C}\right)$, unsaponifiable matter was extracted, then fatty acids recovered with $\mathrm{HCl}$, were extracted, weighted and methylated in methanol with $0.7 \mathrm{M} \mathrm{HCl}$ (3min at $90^{\circ} \mathrm{C}$ ). Fatty acids methyl esters (FAME) were separated by gas chromatography, GC (Auto-system Perkin-Elmer ${ }^{\circledR}$ with a flame ionisation detector, BPX 70 capillary column: $25 \mathrm{~m}$ x $0.22 \mathrm{~mm}$ i.d. $\times 0.25 \mu \mathrm{m}$ film thickness; split-splitless injector, with helium as carrier gas). The injector and detector temperatures were, respectively, 220 and $260^{\circ} \mathrm{C}$. Data acquisition and handling were carried out by connecting the GC to a computer. The individual fatty acid methyl esters were identified by comparing the retention times of 
authentic standard mixtures. FA composition was expressed as percent of total identified FA methyl esters.

Oxygen consumption of fed fish $\left(\mathrm{MO}_{2}-\mathrm{R}, \mathrm{mg} \mathrm{kg}^{-1} \mathrm{~h}^{-1}\right)$ was estimated from the difference in $\mathrm{O}_{2}$-concentration in the inlet and outlet waters of each tank after correction for $\mathrm{O}_{2}$ variations measured in a tank without fish. Measurements were undertaken over 3 consecutive days, by water sampling in each tank twice per hour during one minute. $\mathrm{MO}_{2}-\mathrm{R}$ was calculated as: (outlet $\mathrm{O}_{2}$ - concentration - inlet $\mathrm{O}_{2}$-concentration) $\times \mathrm{Q}_{\mathrm{w}} \mathrm{W}^{-1}$, where $\mathrm{Q}_{\mathrm{w}}=$

flow rate $\left(1\right.$ day $\left.^{-1}\right)$ and wet fish mass (W) was estimated by inference from the growth curve.

\subsection{Data analysis}

All results are expressed as mean \pm SE. Statistical analyses were conducted using Statistica ${ }^{\circledR}$ for Windows. For each parameter, differences between the four experimental conditions versus time were tested by a two-way nested ANOVA, to identify the effects of temperature and diet and their possible interactions. Prior to ANOVA analysis, data expressed in $\%$, were arcsin square-root transformed. When significant interactions were observed, differences between means were compared by a Newman-Keuls test, differences were considered significant at $\mathrm{P}<0.05$.

For comparison of whole fatty acid profiles, we used the coefficient of distance D (McIntire et al., 1969): 


$$
D(h-j)=\left(\sum_{i=1}^{n}(P i h-P i j)^{2}\right)^{1 / 2}
$$

where the $D(h-j)$ is distance between treatments $h$ and $j$, and $P i h$ and $P i j$ are percentage of the fatty acid $i$ in samples $h$ and $j$, for each $i$ fatty acid.

\section{Results}

Temperature remained stable over the 84-day experiment $(\mathrm{CV}$ for temperature was $2 \%$ at $22^{\circ} \mathrm{C}$ and $5 \%$ at $29^{\circ} \mathrm{C}$ ). Water quality was stable in all groups, although there were some differences in ammonia concentration and $\mathrm{pH}$ between the two temperature groups (Table 1). $\mathrm{O}_{2}$-concentrations were close to saturation, averaging $8.1 \mathrm{mg}^{-1}$ at $22^{\circ} \mathrm{C}$ and 7.5 $\operatorname{mg} 1^{-1}$ at $29^{\circ} \mathrm{C}$.

The apparent digestibility of the two diets tested at $22^{\circ} \mathrm{C}$ was very high with the apparent digestibility coefficients (ADC) of protein, fat and energy being in the same range: 97,99 and $88 \%$, respectively.

The changes in mean weight versus time are shown in Fig. 1. For all experimental conditions, there was a two-fold increase in mass. Significant differences in mass gain between the two temperatures and the two diets were observed from day 28 onwards. Final weight in the HD-29 group was $18 \%$ higher than in the LD-22 group having the highest and lowest growth, respectively. On day 84, fish weight dispersion was low in all groups, no significant differences in $\mathrm{CV}$ for weight related to temperature and diets were observed (Table 1). 
Fig.1

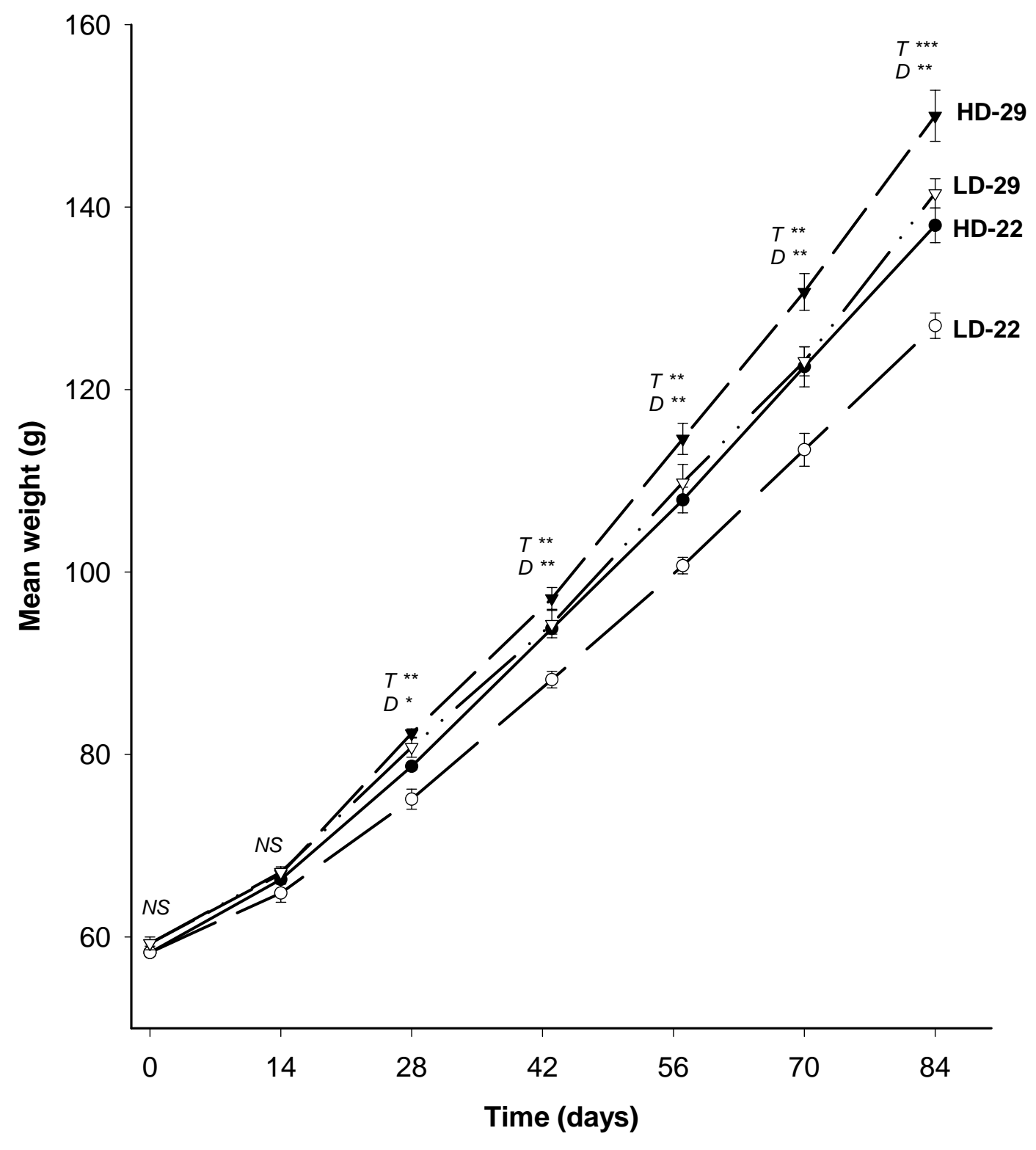

Fig.1- Mean weight increase over time in sea bass fed the two experimental diets at two temperatures: HD-29, HD-22, LD-29 and LD-22. Means are given with standard error $(\mathrm{n}=3)$. Letters $T$ and $D$ indicate significant statistical differences between temperature and diet: *, $\mathrm{P}<0.05$; **, $\mathrm{P}<0.01$ and ${ }^{* * *}, \mathrm{P}<0.001$. NS $=$ no significant difference $(\mathrm{P}>0.05)$. 
Specific growth rate (SGR), feed intake (FI) and feed conversion ratio (FCR) are reported for different periods in Fig. 2. The changes at the end of the acclimation period from a commercial to the experimental diets induced, at $22^{\circ} \mathrm{C}$, a $44-53 \%$ decrease in SGR during the first two weeks (day 0 to 14 ) followed by a significant increase on day 14 to 28 period, i.e. 48 and 51\% for HD and LD regimes, respectively (Fig. 2A). During the day 14 to 28 period, SGR was significantly higher at $29^{\circ} \mathrm{C}$ than at $22^{\circ} \mathrm{C}$. From day 28 until the end of the experiment, it was stabilised around $1 \%$ day $^{-1}$. Over the 84 -day period, SGR was significantly affected both by temperature and $\operatorname{diet}\left(\mathrm{P}=6 \times 10^{-4}\right.$ and $2 \times 10^{-4}$ respectively), averaging 1.01 and 1.07 in HD-22 and HD-29 groups compared to 0.92 and 1.0 in LD-22 and LD-29 groups. 
Fig. 2
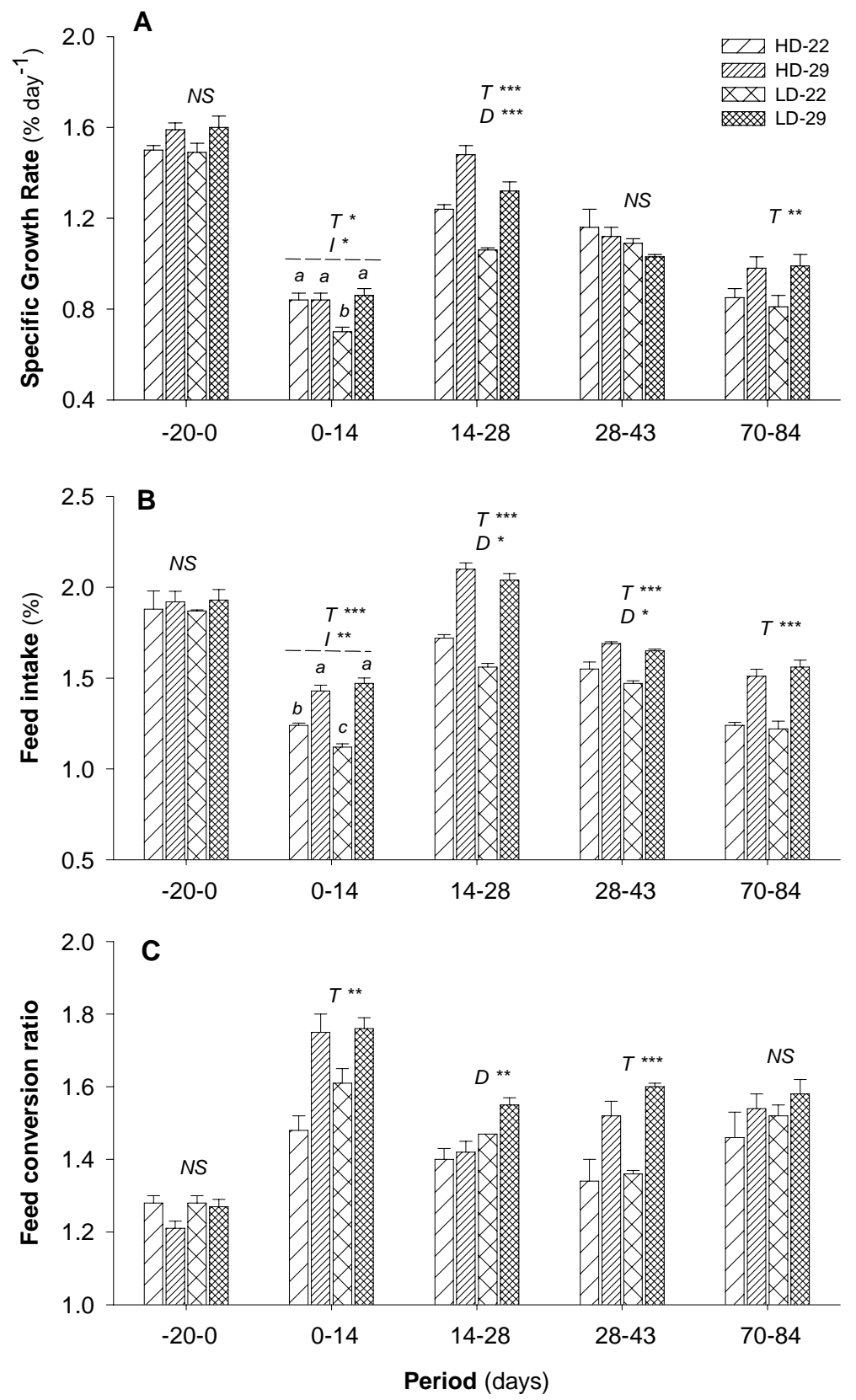

Fig.2- Specific growth rate (A), feed intake (B) and feed conversion ratio (C) for the acclimation period (day 20 to 0 ) and for selected periods of the experiment in relation to the experimental conditions: HD29, HD-22, LD-29 and LD-22. Means are given with standard error $(\mathrm{n}=3)$. Letters $T$ and $D$ indicate significant statistical differences between temperature and diets; letter $I$ indicates temperature and diet interaction. *, $\mathrm{P}<0.05 ; * *, \mathrm{P}<0.01$ and $* * *, \mathrm{P}<0.001$; $\mathrm{NS}=$ no significant difference $(\mathrm{P}>0.05)$. Superscript letters indicate significantly different means (Newmann-Keuls test $\mathrm{P}<0.05$ ). 
Differences in SGR related to the experimental conditions tested were primarily explained by differences in FI (Fig. 2B). The changes at day 0 from a commercial to the experimental diets led to a significant decrease in fish appetite during the first two weeks that was more marked at $22^{\circ} \mathrm{C}$ than at $29^{\circ} \mathrm{C}(37$ and $25 \%$, respectively). A relative increase in FI was observed from day 14 up to the end of the experiment. FI was highly affected by temperature whatever period was $\left(\mathrm{P}=9 \times 10^{-8}\right.$ for day 0 to 84 period $)$ and to a lesser extent by diet ( $\mathrm{P}=0.01$ over the 84 -day experiment). Major changes in feed conversion ratio were transiently caused by the delivery of the experimental diets; at $22^{\circ} \mathrm{C}$ a 14 to $21 \%$ increase in FCR was observed for day 0 to 14 period (Fig. 2C). Over the 84-day period FCR was significantly affected by temperature $\left(\mathrm{P}=1.4 \times 10^{-8}\right)$ and $\operatorname{diet}\left(\mathrm{P}=1 \times 10^{-4}\right)$, averaging 1.41.45 at $22^{\circ} \mathrm{C}$ and $1.6-1.65$ at $29^{\circ} \mathrm{C}$. For growth and feeding parameters, no interaction between the dietary level of n-3 HUFA and temperature was observed.

The oxygen consumption in routine metabolism $\left(\mathrm{MO}_{2}-\mathrm{R}\right)$ was both dependent on temperature and diet (Fig. 3). In 120 to150 g sea bass acclimated to the experimental conditions for 80 days, $\mathrm{MO}_{2}-\mathrm{R}$ was the highest in the HD-29 group $\left(396 \mathrm{mg} \mathrm{O}_{2} \mathrm{~kg}^{-1} \mathrm{~h}^{-1}\right)$. 


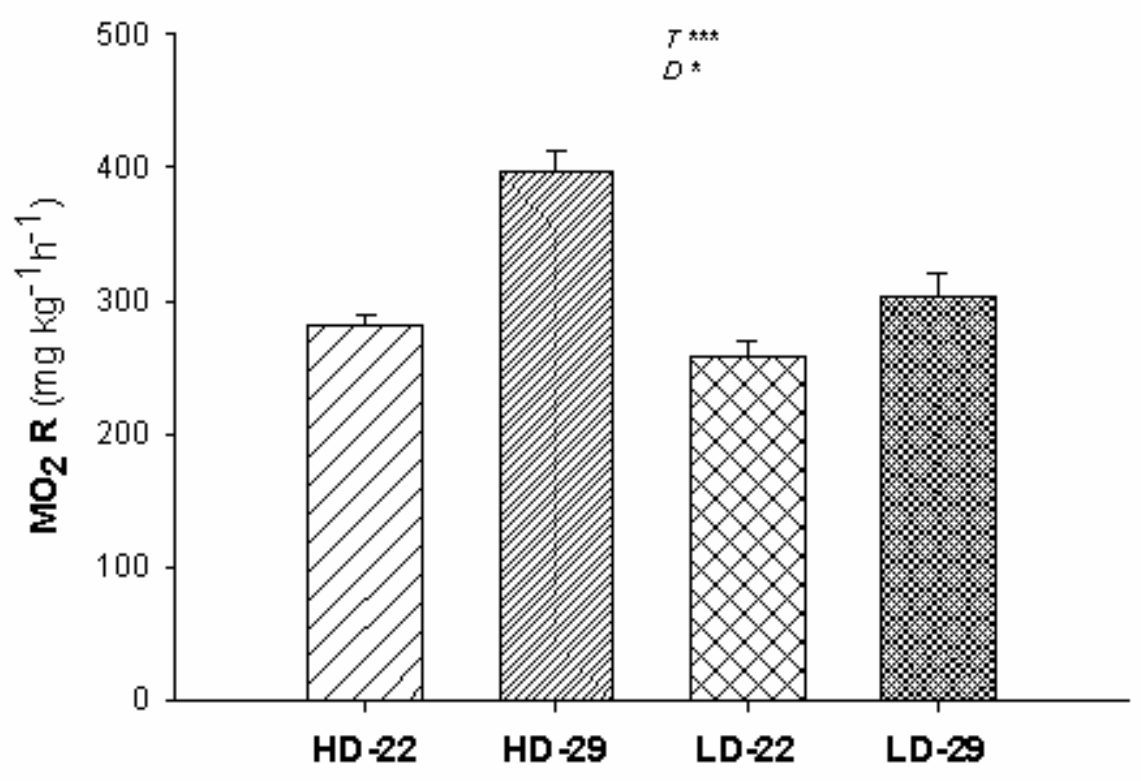

Fig.3- Oxygen consumption of fed fish acclimated to the four experimental conditions for 72 days: HD-29, HD-22, LD-29 and LD-22. Means are given with standard error $(\mathrm{n}=3)$. Letters $T$ and $D$ indicate significant statistical differences between temperature and diets: *, $\mathrm{P}<0.05$ and ${ }^{* * *}, \mathrm{P}<0.001$

Table 4. Initial and final whole body composition (\% wet weight basis) and protein retention (\%) of sea bass at end of the experiment.

\begin{tabular}{lcccccccc}
\hline & Day 0 & \multicolumn{2}{c}{ Day 84} & & \multicolumn{3}{c}{2 way ANOVA } \\
\cline { 3 - 9 } & & 22-HD & 22-LD & 29-HD & 29-LD & Diet & $T^{\circ}$ & D. $x T^{\circ}$ \\
\hline Moisture & $63.2 \pm 0.5$ & $61.7 \pm 0.7$ & $61.8 \pm 0.3$ & $60.1 \pm 0.6$ & $60.0 \pm 0.2$ & $n s$ & $*$ & $n s$ \\
Protein & $16.4 \pm 0.1$ & $16.7 \pm 0.6$ & $16.2 \pm 0.3$ & $16.2 \pm 0.2$ & $15.4 \pm 0.5$ & $n s$ & $n s$ & $n s$ \\
Fat & $16.1 \pm 0.6$ & $16.3 \pm 0.7$ & $17.1 \pm 0.5$ & $18.1 \pm 0.4$ & $18.4 \pm 0.6$ & $n s$ & $n s$ & $n s$ \\
Protein retention & & $25.3 \pm 1.5$ & $22.7 \pm 0.5$ & $18.9 \pm 0.7$ & $15.9 \pm 1.0$ & $*$ & $* * *$ & $n s$ \\
\hline
\end{tabular}

Values are means \pm standard error $(\mathrm{n}=3) .2$ way ANOVA statistical results: $* \mathrm{P}<0.05 ; * * * \mathrm{P}<0.001$; ns: not significant. 
On day 84 , there was no major difference in fish whole body composition despite a slight increase in lipid with temperature (NS) concomitant to a significant decrease in moisture content (Table 4). Protein retention was significantly affected by temperature $\left(\mathrm{P}=2 \times 10^{-4}\right)$ and to a lesser extent by $\operatorname{diet}(\mathrm{P}=0.02)$.

Fish initial and final fatty acid composition of total lipids are shown in Table 5. Compared to day 0 , the $18: 1 n-9$ and 18:2n-6 contents were markedly higher for LD than for $\mathrm{HD}$ in the $22^{\circ} \mathrm{C}$ groups. The same trend was observed for $18: 3 \mathrm{n}-3$. Conversely, the fatty acids of marine origin (DHA, EPA and 22:1n-11) decreased with time. On day 84, a significantly effect of the diets was observed for most fatty acids. Significant effects of temperature were also observed on some fatty acid contents: at $29^{\circ} \mathrm{C}$ there was an increase in 18:0, 18:2n-6 and 18:3n-3 and a decrease in 16:1n-7, 18:1n-7 and 22:1n-11. Main HUFAs (DHA and EPA) and arachidonic acid were affected by the two factors with a significant interaction resulting from significant decreases in 29-LD compared to 22-LD groups, while 29-HD and 22-HD groups were not significantly different. Fatty acid patterns in neutral lipids were quite similar as those found in total lipids for each experimental condition (Table 6). For most fatty acids the same effects of diet and temperature were observed with some changes on significance levels. No effect of diet was observed on 18:0; a significant difference appeared on 18:3n-6, higher if fish fed LD (a fatty acid not detected in diet LD); no interaction was observed for arachidonic acid content while an interaction was found in $22: 1 \mathrm{n}-11$ decreasing at $29^{\circ} \mathrm{C}$ only in fish fed diet LD. 
Table 5. Fatty acid composition of total lipids from whole body (area \%), in initial fish (day 0) and at the end of experiment..

\begin{tabular}{|c|c|c|c|c|c|c|c|c|}
\hline \multirow[t]{2}{*}{ Fatty acids } & \multirow[t]{2}{*}{ Day 0} & \multicolumn{4}{|l|}{ Day 84} & \multicolumn{3}{|c|}{2 way $A N O V A$} \\
\hline & & 22-HD & 22-LD & 29-HD & 29-LD & Diet & $T^{\circ}$ & $\operatorname{Diet} x T^{\circ}$ \\
\hline$\sum$ saturates & $21.1 \pm 0.1$ & $24.1 \pm 0.1^{\mathrm{b}}$ & $20.7 \pm 0.3^{c}$ & $24.7 \pm 0.1^{\mathrm{a}}$ & $20.3 \pm 0.1^{\mathrm{c}}$ & $* * *$ & $n s$ & $*$ \\
\hline $14: 0$ & $4.5 \pm 0.0$ & $3.6 \pm 0.0^{b}$ & $3.6 \pm 0.0^{c}$ & $3.6 \pm 0.0^{\mathrm{a}}$ & $3.6 \pm 0.0^{\mathrm{d}}$ & $* * *$ & $n s$ & $* * *$ \\
\hline $16: 0$ & $18.7 \pm 0.1$ & $16.6 \pm 0.2$ & $14.3 \pm 0.2$ & $16.7 \pm 0.1$ & $13.9 \pm 0.1$ & $* * *$ & $n s$ & $n s$ \\
\hline $18: 0$ & $3.6 \pm 0.0$ & $3.1 \pm 0.0$ & $3.0 \pm 0.0$ & $3.5 \pm 0.0$ & $3.3 \pm 0.0$ & $* * *$ & $* * *$ & $n s$ \\
\hline $20: 0$ & $0.2 \pm 0.0$ & $0.3 \pm 0.0$ & $0.4 \pm 0.0$ & $0.4 \pm 0.0$ & $0.4 \pm 0.0$ & $* * *$ & $n s$ & $n s$ \\
\hline $22: 0$ & $0.1 \pm 0.0$ & $0.4 \pm 0.0$ & $0.4 \pm 0.0$ & $0.4 \pm 0.0$ & $0.4 \pm 0.0$ & $n s$ & * & $n s$ \\
\hline$\Sigma$ monoenes & $43.1 \pm 0.2$ & $47.7 \pm 0.2^{\mathrm{b}}$ & $52.4 \pm 0.1^{\mathrm{a}}$ & $46.8 \pm 0.2^{\mathrm{c}}$ & $52.9 \pm 0.1^{\mathrm{a}}$ & $* * *$ & $n s$ & $* * *$ \\
\hline $16: 1 n-7$ & $5.8 \pm 0.0$ & $5.0 \pm 0.0^{\mathrm{a}}$ & $3.6 \pm 0.1^{\mathrm{c}}$ & $4.7 \pm 0.1^{b}$ & $3.1 \pm 0.0^{\mathrm{d}}$ & $* * *$ & $* * *$ & * \\
\hline $18: 1 n-7$ & $3.0 \pm 0.0$ & $3.0 \pm 0.0$ & $3.0 \pm 0.0$ & $2.9 \pm 0.0$ & $2.9 \pm 0.0$ & * & $* * *$ & $n s$ \\
\hline $18: 1 n-9$ & $19.7 \pm 0.2$ & $27.9 \pm 0.4^{\mathrm{c}}$ & $37.2 \pm 0.2^{b}$ & $27.4 \pm 0.3^{\mathrm{c}}$ & $38.9 \pm 0.1^{\mathrm{a}}$ & $* * *$ & $n s$ & $* *$ \\
\hline $20: 1 n-9$ & $5.7 \pm 0.0$ & $5.4 \pm 0.1$ & $4.3 \pm 0.0$ & $5.3 \pm 0.1$ & $4.1 \pm 0.0$ & $* * *$ & $* *$ & $n s$ \\
\hline 24:1n-9 & $0.3 \pm 0.0$ & $0.3 \pm 0.0$ & $0.2 \pm 0.0$ & $0.3 \pm 0.0$ & $0.2 \pm 0.0$ & $* *$ & $n s$ & $n s$ \\
\hline $22: 1 n-11$ & $5.2 \pm 0.1$ & $3.6 \pm 0.1$ & $2.3 \pm 0.0$ & $3.5 \pm 0.0$ & $2.1 \pm 0.0$ & $* * *$ & $* * *$ & $n s$ \\
\hline$\sum n-6$ & $8.9 \pm 0.3$ & $9.4 \pm 0.2$ & $13.4 \pm 0.2$ & $9.6 \pm 0.0$ & $13.7 \pm 0.1$ & $* * *$ & $n s$ & $n s$ \\
\hline $18: 2 n-6$ & $7.4 \pm 0.1$ & $8.0 \pm 0.2$ & $12.1 \pm 0.2$ & $8.2 \pm 0.0$ & $12.5 \pm 0.1$ & $* * *$ & $*$ & $n s$ \\
\hline $18: 3 n-6$ & $0.3 \pm 0.0$ & $0.3 \pm 0.0$ & $0.3 \pm 0.0$ & $0.3 \pm 0.0$ & $0.3 \pm 0.0$ & $n s$ & $n s$ & $n s$ \\
\hline $20: 2 n-6$ & $0.4 \pm 0.0$ & $0.5 \pm 0.0$ & $0.5 \pm 0.0$ & $0.4 \pm 0.0$ & $0.4 \pm 0.0$ & $n s$ & $n s$ & $n s$ \\
\hline $20: 3 n-6$ & $0.1 \pm 0.0$ & $0.1 \pm 0.0$ & $0.1 \pm 0.0$ & $0.1 \pm 0.0$ & $0.1 \pm 0.0$ & $*$ & $n s$ & $n s$ \\
\hline $20: 4 n-6$ & $0.4 \pm 0.0$ & $0.4 \pm 0.0^{\mathrm{a}}$ & $0.2 \pm 0.0^{\mathrm{b}}$ & $0.4 \pm 0.0^{\mathrm{a}}$ & $0.2 \pm 0.0^{\mathrm{c}}$ & $* * *$ & $* *$ & * \\
\hline$\sum n-3$ & $20.4 \pm 0.2$ & $18.7 \pm 0.2$ & $13.6 \pm 0.2$ & $18.9 \pm 0.1$ & $13.1 \pm 0.1$ & $* * *$ & $n s$ & $n s$ \\
\hline $18: 3 n-3$ & $1.5 \pm 0.0$ & $2.7 \pm 0.1$ & $4.3 \pm 0.1$ & $2.9 \pm 0.0$ & $4.7 \pm 0.0$ & $* * *$ & $* * *$ & $n s$ \\
\hline $18: 4 n-3$ & $1.7 \pm 0.0$ & $1.3 \pm 0.0^{\mathrm{a}}$ & $0.9 \pm 0.0^{\mathrm{b}}$ & $1.4 \pm 0.0^{\mathrm{a}}$ & $0.9 \pm 0.0^{\mathrm{c}}$ & $* * *$ & $n s$ & $* *$ \\
\hline $20: 4 n-3$ & $0.5 \pm 0.0$ & $0.6 \pm 0.0^{b}$ & $0.3 \pm 0.0^{\mathrm{c}}$ & $0.6 \pm 0.0^{\mathrm{a}}$ & $0.2 \pm 0.0^{\mathrm{d}}$ & $* * *$ & $n s$ & $* * *$ \\
\hline$\Sigma n-3$ HUFA & $16.5 \pm 0.1$ & $14.0 \pm 0.1^{\mathrm{a}}$ & $8.0 \pm 0.1^{\mathrm{b}}$ & $13.8 \pm 0.1^{\mathrm{a}}$ & $7.1 \pm 0.1^{\mathrm{c}}$ & $* * *$ & $* * *$ & $* *$ \\
\hline $20: 5 n-3$ & $6.7 \pm 0.0$ & $5.5 \pm 0.1^{\mathrm{a}}$ & $3.2 \pm 0.0^{\mathrm{b}}$ & $5.4 \pm 0.1^{\mathrm{a}}$ & $2.8 \pm 0.0^{\mathrm{c}}$ & $* * *$ & $* * *$ & $* * *$ \\
\hline $22: 5 n-3$ & $1.0 \pm 0.0$ & $1.1 \pm 0.0^{\mathrm{a}}$ & $0.5 \pm 0.0^{\mathrm{b}}$ & $1.2 \pm 0.0^{\mathrm{a}}$ & $0.4 \pm 0.0^{\mathrm{c}}$ & $* * *$ & $n s$ & * \\
\hline $22: 6 n-3$ & $8.9 \pm 0.1$ & $7.3 \pm 0.0^{\mathrm{a}}$ & $4.3 \pm 0.1^{\mathrm{b}}$ & $7.2 \pm 0.0^{\mathrm{a}}$ & $3.9 \pm 0.0^{\mathrm{c}}$ & $* * *$ & $* * *$ & ** \\
\hline
\end{tabular}

Values are means \pm standard error $(n=6)$. 2 way ANOVA statistical results: $* \mathrm{P}<0.05 ; * * \mathrm{P}<0.01 ; * * * \mathrm{P}<0.001$; ns: not significant. In case of significant interaction means having different superscript letter in the same raw are significantly different (Newmann-Keuls test, $\mathrm{P}<0.05$ ) 
Table 6. Fatty acid composition of neutral lipids from whole body (area \%), in initial fish (day 0) and at the end of experiment.

\begin{tabular}{|c|c|c|c|c|c|c|c|c|}
\hline \multirow[t]{2}{*}{ Fatty acid } & \multirow[t]{2}{*}{ Day 0} & \multicolumn{4}{|l|}{ Day 84} & \multicolumn{3}{|c|}{2 way $A N O V A$} \\
\hline & & $22-\mathrm{HD}$ & 22-LD & 29-HD & 29-LD & Diet & $T^{\circ}$ & $\operatorname{Diet} x T^{\circ}$ \\
\hline$\sum$ saturates & $25.5 \pm 0.3$ & $22.5 \pm 0.2$ & $19.8 \pm 0.2$ & $23.1 \pm 0.5$ & $19.7 \pm 0.2$ & $* * *$ & $n s$ & $n s$ \\
\hline 14:0 & $4.4 \pm 0.1$ & $3.4 \pm 0.1^{\mathrm{a}}$ & $2.3 \pm 0.1^{\mathrm{b}}$ & $3.5 \pm 0.1^{\mathrm{a}}$ & $2.1 \pm 0.1^{\mathrm{c}}$ & *** & $n s$ & ** \\
\hline $16: 0$ & $17.5 \pm 0.5$ & $15.4 \pm 0.4$ & $13.7 \pm 0.4$ & $15.5 \pm 0.8$ & $13.4 \pm 0.3$ & $* * *$ & $n s$ & $n s$ \\
\hline 18:0 & $3.3 \pm 0.1$ & $2.9 \pm 0.1$ & $2.9 \pm 0.1$ & $3.2 \pm 0.3$ & $3.2 \pm 0.1$ & $n s$ & $* * *$ & $n s$ \\
\hline $20: 0$ & $0.2 \pm 0.0$ & $0.3 \pm 0.0$ & $0.4 \pm 0.0$ & $0.3 \pm 0.0$ & $0.4 \pm 0.0$ & $* * *$ & * & $n s$ \\
\hline $22: 0$ & $0.1 \pm 0.0$ & $0.4 \pm 0.0$ & $0.4 \pm 0.1$ & $0.4 \pm 0.0$ & $0.5 \pm 0.0$ & $n s$ & $* *$ & $n s$ \\
\hline$\Sigma$ monoenes & $44.2 \pm 0.1$ & $48.9 \pm 0.2^{b}$ & $53.2 \pm 0.1^{\mathrm{a}}$ & $47.7 \pm 0.2^{\mathrm{c}}$ & $53.5 \pm 0.1^{\mathrm{a}}$ & $* * *$ & * & $* * *$ \\
\hline $16: 1 n-7$ & $5.8 \pm 0.1$ & $4.9 \pm 0.1^{\mathrm{a}}$ & $3.2 \pm 0.2^{\mathrm{c}}$ & $4.6 \pm 0.1^{\mathrm{b}}$ & $2.7 \pm 0.1^{\mathrm{d}}$ & $* * *$ & $* * *$ & $*$ \\
\hline $18: 1 n-7$ & $2.9 \pm 0.0$ & $2.9 \pm 0.0$ & $2.8 \pm 0.0$ & $2.8 \pm 0.0$ & $2.7 \pm 0.0$ & $* * *$ & $* * *$ & $n s$ \\
\hline $18: 1 n-9$ & $20.3 \pm 0.5$ & $28.0 \pm 0.5^{\mathrm{c}}$ & $38.0 \pm 0.3^{\mathrm{b}}$ & $27.5 \pm 0.3^{\mathrm{d}}$ & $39.5 \pm 0.1^{\mathrm{a}}$ & $* * *$ & $* *$ & $* * *$ \\
\hline $20: 1 n-9$ & $6.1 \pm 0.1$ & $5.8 \pm 0.2^{\mathrm{a}}$ & $4.7 \pm 0.1^{\mathrm{b}}$ & $5.8 \pm 0.1^{\mathrm{a}}$ & $4.5 \pm 0.1^{\mathrm{c}}$ & $* * *$ & $n s$ & * \\
\hline $24: 1 n-9$ & $0.4 \pm 0.0$ & $0.6 \pm 0.4$ & $0.3 \pm 0.0$ & $0.3 \pm 0.0$ & $0.3 \pm 0.0$ & * & $n s$ & $n s$ \\
\hline $22: 1 n-11$ & $5.7 \pm 0.1$ & $3.9 \pm 0.1^{\mathrm{a}}$ & $2.6 \pm 0.1^{\mathrm{b}}$ & $3.9 \pm 0.1^{\mathrm{a}}$ & $2.4 \pm 0.1^{\mathrm{c}}$ & $* * *$ & $* *$ & ** \\
\hline$\sum n-6$ & $8.9 \pm 0.1$ & $9.2 \pm 0.2$ & $13.2 \pm 0.2$ & $9.6 \pm 0.1$ & $13.5 \pm 0.1$ & $* * *$ & * & $n s$ \\
\hline $18: 2 n-6$ & $7.7 \pm 0.1$ & $8.0 \pm 0.4$ & $12.1 \pm 0.4$ & $8.4 \pm 0.3$ & $12.5 \pm 0.3$ & $* * *$ & * & $n s$ \\
\hline $18: 3 n-6$ & $0.2 \pm 0.0$ & $0.2 \pm 0.0$ & $0.3 \pm 0.0$ & $0.2 \pm 0.0$ & $0.3 \pm 0.0$ & $* * *$ & $n s$ & $n s$ \\
\hline $20: 2 n-6$ & $0.4 \pm 0.0$ & $0.5 \pm 0.0$ & $0.5 \pm 0.0$ & $0.5 \pm 0.0$ & $0.5 \pm 0.0$ & $n s$ & $n s$ & $n s$ \\
\hline $20: 3 n-6$ & $0.1 \pm 0.0$ & $0.1 \pm 0.0$ & $0.1 \pm 0.0$ & $0.1 \pm 0.0$ & $0.1 \pm 0.1$ & $* * *$ & $n s$ & $n s$ \\
\hline $20: 4 n-6$ & $0.4 \pm 0.0$ & $0.3 \pm 0.0$ & $0.2 \pm 0.0$ & $0.3 \pm 0.0$ & $0.2 \pm 0.0$ & $* * *$ & * & $n s$ \\
\hline$\sum n-3$ & $21.2 \pm 0.1$ & $19.3 \pm 0.2^{\mathrm{a}}$ & $13.8 \pm 0.2^{\mathrm{b}}$ & $19.6 \pm 0.2^{\mathrm{a}}$ & $13.3 \pm 0.0^{\mathrm{c}}$ & $* * *$ & $n s$ & $* *$ \\
\hline $18: 3 n-3$ & $1.7 \pm 0.0$ & $2.9 \pm 0.2$ & $4.5 \pm 0.2$ & $3.1 \pm 0.1$ & $4.8 \pm 0.1$ & $* * *$ & $* * *$ & $n s$ \\
\hline $18: 4 n-3$ & $1.9 \pm 0.0$ & $1.4 \pm 0.0^{\mathrm{a}}$ & $1.0 \pm 0.0^{\mathrm{b}}$ & $1.4 \pm 0.0^{\mathrm{a}}$ & $0.9 \pm 0.0^{\mathrm{c}}$ & $* * *$ & $*$ & $*$ \\
\hline $20: 4 n-3$ & $0.6 \pm 0.0$ & $0.6 \pm 0.0^{\mathrm{b}}$ & $0.3 \pm 0.0^{\mathrm{c}}$ & $0.7 \pm 0.0^{\mathrm{a}}$ & $0.3 \pm 0.0^{\mathrm{d}}$ & $* * *$ & $n s$ & $* * *$ \\
\hline$\sum n-3$ HUFA & $16.9 \pm 0.1$ & $14.1 \pm 0.1^{\mathrm{a}}$ & $7.8 \pm 0.2^{\mathrm{b}}$ & $14.2 \pm 0.1 \mathrm{a}$ & $7.1 \pm 0.0^{\mathrm{c}}$ & $* * *$ & * & $* *$ \\
\hline $20: 5 n-3$ & $6.8 \pm 0.1$ & $5.6 \pm 0.1^{\mathrm{a}}$ & $3.2 \pm 0.2^{\mathrm{b}}$ & $5.5 \pm 0.2^{\mathrm{a}}$ & $2.7 \pm 0.0^{\mathrm{c}}$ & $* * *$ & $* * *$ & $* * *$ \\
\hline $22: 5 n-3$ & $1.1 \pm 0.0$ & $1.2 \pm 0.1^{\mathrm{a}}$ & $0.5 \pm 0.0^{\mathrm{b}}$ & $1.3 \pm 0.0^{\mathrm{a}}$ & $0.4 \pm 0.0^{\mathrm{c}}$ & $* * *$ & $n s$ & * \\
\hline $22: 6 n-3$ & $9.0 \pm 0.1$ & $7.3 \pm 0.1^{\mathrm{a}}$ & $4.1 \pm 0.2^{\mathrm{b}}$ & $7.4 \pm 0.1^{\mathrm{a}}$ & $3.9 \pm 0.1^{\mathrm{c}}$ & $* * *$ & $n s$ & $*$ \\
\hline
\end{tabular}

Values are means \pm standard error $(n=6) .2$ way ANOVA statistical results: $* \mathrm{P}<0.05 ; * * \mathrm{P}<0.01 ; * * * \mathrm{P}<0.001$; ns: not significant. In case of interaction, superscript letters indicate significantly different means (Newmann-Keuls test $\mathrm{P}<0.05$ ) 
In polar lipids, n-3 HUFA, 20:4n-6, 16:0 and 18:0 fish contents were higher than the corresponding values in total lipid for each treatment (Table 7). A significant effect of diet was observed for the main fatty acids, according to their relative values in diets. However, the 18:3n-6 contents were significant higher in fish fed LD than in fish fed HD. A significant effect of temperature was observed for several fatty acids: DHA, DPA (22:5n3), $18: 3 \mathrm{n}-3,20: 3 \mathrm{n}-6,20: 2 \mathrm{n}-6$, and $18: 1 \mathrm{n}-7$ were lower at $29^{\circ} \mathrm{C}$ than at $22^{\circ} \mathrm{C}$, while $18: 1 \mathrm{n}-9$ and 16:0 were higher at $22^{\circ} \mathrm{C}$ (no interaction between temperature and diet).

The D values (Table 8) let to observe the magnitude of studied factors on whole fatty acid profiles. For total lipids a strong effect of diets appeared, distances between diets being slightly higher at $29(\mathrm{D}=13.7)$ than at $22^{\circ} \mathrm{C}(\mathrm{D}=11.6)$. In opposite distances due to temperature were very low ( $\mathrm{D}=0.9$ within $\mathrm{HD}$ groups and 2.0 within $\mathrm{LD}$ groups). The $\mathrm{D}$ values for neutral lipids were relatively similar to those observed in total lipids. In polar lipids the major effect was also due to diet $(\mathrm{D}=9.1-9.8)$, however temperature had here a noticeable effect $(\mathrm{D}=4.6-5.5)$. 
Table 7. Fatty acid composition of polar lipids from whole body (area \%), in initial fish (day 0 ) and at the end of experiment..

\begin{tabular}{|c|c|c|c|c|c|c|c|c|}
\hline \multirow[t]{2}{*}{ Fatty acid } & \multirow[t]{2}{*}{ Day 0} & \multicolumn{4}{|l|}{ Day 84} & \multicolumn{3}{|c|}{2 way $A N O V A$} \\
\hline & & 22-HD & 22-LD & 29-HD & 29-LD & Diet & $T^{\circ}$ & Diet $x T^{\circ}$ \\
\hline$\sum$ saturates & $32.7 \pm 0.2$ & $29.1 \pm 1.3$ & $28.6 \pm 0.6$ & $32.8 \pm 1.4$ & $31.1 \pm 1.2$ & $n s$ & $*$ & $n s$ \\
\hline $14: 0$ & $2.0 \pm 0.1$ & $1.5 \pm 0.1$ & $1.4 \pm 0.2$ & $1.8 \pm 0.2$ & $1.5 \pm 0.4$ & $n s$ & $n s$ & $n s$ \\
\hline $16: 0$ & $19.3 \pm 0.1$ & $18.1 \pm 0.5$ & $16.5 \pm 0.4$ & $19.3 \pm 0.5$ & $17.2 \pm 0.4$ & $* * *$ & $*$ & $n s$ \\
\hline $18: 0$ & $10.6 \pm 0.1$ & $8.6 \pm 0.7$ & $9.7 \pm 0.5$ & $10.8 \pm 1.5$ & $11.6 \pm 1.0$ & $n s$ & $n s$ & $n s$ \\
\hline $20: 0$ & $0.4 \pm 0.0$ & $0.3 \pm 0.0$ & $0.5 \pm 0.1$ & $0.3 \pm 0.0$ & $0.4 \pm 0.1$ & $* *$ & $n s$ & $n s$ \\
\hline $22: 0$ & $0.2 \pm 0.0$ & $0.3 \pm 0.0$ & $0.5 \pm 0.1$ & $0.3 \pm 0.0$ & $0.3 \pm 0.0$ & $n s$ & $n s$ & $n s$ \\
\hline$\Sigma$ monenes. & $24.0 \pm 0.4$ & $23.7 \pm 0.4$ & $28.0 \pm 0.2$ & $25.5 \pm 0.2$ & $30.8 \pm 0.1$ & $* * *$ & $* * *$ & $n s$ \\
\hline $16: 1 n-7$ & $1.8 \pm 0.1$ & $1.3 \pm 0.1$ & $1.2 \pm 0.1$ & $1.2 \pm 0.1$ & $1.3 \pm 0.1$ & $n s$ & $n s$ & $n s$ \\
\hline $18: 1 n-7$ & $2.1 \pm 0.0$ & $2.1 \pm 0.0$ & $2.2 \pm 0.0$ & $1.8 \pm 0.1$ & $2.0 \pm 0.1$ & $*$ & $* *$ & $n s$ \\
\hline $18: 1 n-9$ & $14.3 \pm 0.2$ & $15.7 \pm 0.1$ & $20.1 \pm 0.2$ & $18.0 \pm 0.4$ & $22.3 \pm 0.6$ & $* * *$ & $* * *$ & $n s$ \\
\hline $20: 1 n-9$ & $1.8 \pm 0.1$ & $1.6 \pm 0.3$ & $1.6 \pm 0.0$ & $1.4 \pm 0.1$ & $1.3 \pm 0.1$ & $n s$ & $n s$ & $n s$ \\
\hline $24: 1 n-9$ & $0.9 \pm 0.1$ & $0.9 \pm 0.1$ & $1.0 \pm 0.1$ & $0.9 \pm 0.1$ & $0.8 \pm 0.1$ & $n s$ & $n s$ & $n s$ \\
\hline $22: 1 n-11$ & $0.7 \pm 0.0$ & $0.4 \pm 0.0$ & $0.3 \pm 0.0$ & $0.5 \pm 0.1$ & $0.4 \pm 0.0$ & $* * *$ & $n s$ & $n s$ \\
\hline$\sum n-6$ & $7.5 \pm 0.1$ & $7.7 \pm 0.2$ & $12.3 \pm 0.2$ & $7.5 \pm 0.3$ & $11.3 \pm 0.4$ & $* * *$ & $n s$ & $n s$ \\
\hline $18: 2 n-6$ & $3.9 \pm 0.1$ & $4.0 \pm 0.1$ & $8.9 \pm 0.2$ & $3.5 \pm 0.3$ & $8.1 \pm 0.5$ & $* * *$ & $n s$ & $n s$ \\
\hline $18: 3 n-6$ & $0.2 \pm 0.0$ & $0.1 \pm 0.0$ & $0.4 \pm 0.0$ & $0.1 \pm 0.0$ & $0.3 \pm 0.1$ & $* *$ & $n s$ & $n s$ \\
\hline $20: 2 n-6$ & $0.6 \pm 0.0$ & $0.6 \pm 0.0$ & $0.8 \pm 0.0$ & $0.5 \pm 0.0$ & $0.6 \pm 0.0$ & $* * *$ & $* *$ & $n s$ \\
\hline $20: 3 n-6$ & $0.2 \pm 0.0$ & $0.2 \pm 0.0$ & $0.3 \pm 0.1$ & $0.1 \pm 0.1$ & $0.2 \pm 0.0$ & $n s$ & $*$ & $n s$ \\
\hline $20: 4 n-6$ & $1.9 \pm 0.0$ & $2.2 \pm 0.1$ & $1.4 \pm 0.1$ & $2.5 \pm 0.1$ & $1.5 \pm 0.1$ & $* * *$ & $n s$ & $n s$ \\
\hline$\sum n-3$ & $36.0 \pm 0.3$ & $39.9 \pm 1.5$ & $31.2 \pm 0.6$ & $34.5 \pm 1.1$ & $26.8 \pm 0.9$ & $* * *$ & $* * *$ & $n s$ \\
\hline $18: 3 n-3$ & $0.5 \pm 0.0$ & $1.0 \pm 0.0$ & $2.2 \pm 0.1$ & $0.9 \pm 0.1$ & $2.0 \pm 0.1$ & $* * *$ & $*$ & $n s$ \\
\hline $18: 4 n-3$ & $0.7 \pm 0.0$ & $0.4 \pm 0.0$ & $0.5 \pm 0.0$ & $0.4 \pm 0.0$ & $0.4 \pm 0.0$ & $n s$ & $n s$ & $n s$ \\
\hline $20: 4 n-3$ & $0.4 \pm 0.0$ & $0.4 \pm 0.0$ & $0.2 \pm 0.0$ & $0.4 \pm 0.0$ & $0.2 \pm 0.0$ & $* *$ & $n s$ & $n s$ \\
\hline$\sum n-3 H U F A$ & $33.7 \pm 0.3$ & $37.9 \pm 1.6$ & $27.8 \pm 0.7$ & $32.8 \pm 1.2$ & $23.8 \pm 1.0$ & $* * *$ & $* * *$ & $n s$ \\
\hline $20: 5 n-3$ & $10.4 \pm 0.1$ & $10.4 \pm 0.3$ & $6.5 \pm 0.3$ & $9.9 \pm 0.5$ & $6.1 \pm 0.4$ & $* * *$ & $n s$ & $n s$ \\
\hline $22: 5 n-3$ & $0.9 \pm 0.0$ & $1.7 \pm 0.1$ & $1.0 \pm 0.2$ & $1.1 \pm 0.1$ & $0.6 \pm 0.0$ & $* * *$ & $* * *$ & $n s$ \\
\hline $22: 6 n-3$ & $22.4 \pm 0.2$ & $25.8 \pm 1.2$ & $20.3 \pm 0.7$ & $21.7 \pm 1.2$ & $17.2 \pm 1.0$ & $* * *$ & $* *$ & $n s$ \\
\hline
\end{tabular}

Values are means \pm standard error $(n=6) .2$ way ANOVA statistical results: $* \mathrm{P}<0.05 ; * * \mathrm{P}<0.01 ; * * * \mathrm{P}<0.001$; ns: not significant. 
Table 8. Comparison of fatty acid profiles by McIntyre distance coefficient (D)

\begin{tabular}{lcccc}
\hline & \multicolumn{2}{c}{ Diet comparison } & \multicolumn{2}{c}{ Temperature comparison } \\
\cline { 2 - 5 } & 22-HD/22-LD & 29-HD/29-LD & 22-HD/29-HD & 22-LD/29-LD \\
\hline Total lipid & 11.6 & 13.7 & 0.9 & 2.0 \\
Neutral lipid & 12.2 & 14.2 & 0.8 & 1.8 \\
Polar lipid & 9.8 & 9.1 & 5.5 & 4.6 \\
\hline
\end{tabular}

\section{Discussion}

This study brought new findings on the possible consequence of a n-3 HUFA dietary deficiency in juvenile sea bass growth in relation to temperature, sub-optimal or close to the upper limit for long-term growth. Temperature had a stronger effect on growth performance than n-3 HUFA, without interaction, at least in fish held in high water quality for 3 months and fed to satiation. Mass gain was high in all groups, the final to initial mass ratio range was 2.2-2.5 (HD-29 to LD-22 groups). The thermal response in terms of growth was in agreement with results reported under similar rearing conditions in sea bass $(80 \mathrm{~g})$ from the same geographic origin and fed a commercial diet: specific growth rate was maximum at $26^{\circ} \mathrm{C}$ and was 12 and $6 \%$ lower at 22 and $29^{\circ} \mathrm{C}$, respectively (Person-Le Ruyet et al., 2004). Growth rate at $22^{\circ} \mathrm{C}$ with $\mathrm{HD}$ was in the range of the upper values reported for juvenile sea bass (Ballestrazzi et al., 1998; Lanari et al., 1999, Pichavant et al., 2001; Lemarié et al., 2003; Person-Le Ruyet et al., 2004). Growth in the 22-HD group was also similar to that of a control tank maintained on the initial commercial diet (SGR 1.02 and 1.03 , respectively). The difference in growth between the two diets confirmed that LD with $0.4 \% \mathrm{n}-3$ HUFA was a deficient diet, the minimal level for growth being $0.7 \% \mathrm{DM}$ (Skalli and Robin, 2004). This deficiency induced similar growth limitation at 22 and $29^{\circ} \mathrm{C}$. 
Growth responses to temperature and diet resulted from joined feeding and metabolic adjustments as generally observed in fish (Jobling, 1997). The present study confirms the capacity of juvenile sea bass to adapt to high temperature $\left(29^{\circ} \mathrm{C}\right)$ when $\mathrm{O}_{2}$ concentration and feed supply were not restricting, by increasing feed intake (FI) and $\mathrm{O}_{2}$ comsumption to compensate for elevated maintenance costs. The relatively low differences in growth related to temperature resulted from both the $17 \%$ increase in $\mathrm{FI}$ from 22 to $29^{\circ} \mathrm{C}$ and the concomitant $12 \%$ increase in feed conversion ratio. FI response to temperature was lower than in a previous study (12 compared to 17\%) while feed conversion ratio was affected in the same way (Person-Le Ruyet et al., 2004). The use of a two factorial design contributes to a better discrimination of the temperature effect. $\mathrm{O}_{2}$-consumption of fed fish was about 41 to $18 \%$ higher at $29^{\circ} \mathrm{C}$ than at $22^{\circ} \mathrm{C}$ depending on the diet. This is in general agreement with results obtained by Claireaux and Lagardère (1999) for larger sea bass $(620 \mathrm{~g})$ and in 60-80 g fish (Pichavant et al., 2001; Person-Le Ruyet et al., 2004).

The initial decrease in FI induced by the change from a commercial diet to the two experimental diets may have several origins but is partly explained by the use of vegetable sources in order to obtain the low HUFA level. Over the experimental period, the slight differences in FI were in the same range at 22 and $29^{\circ} \mathrm{C}$ for each diet. When animals are fed deficient diets, two opposite responses can be induced: an increase in feed intake to reach requirement level when deficiency is mild, or an inhibition when deficiency is higher (de la Higuera, 2001). In the present study, deficiency also increased feed conversion ratio and decreased protein retention, as was previously reported (Ibeas et al., 1994; Lee et al., 2003). 
Whole body composition at the end of the experiment was quite similar for both experimental conditions. The lower nitrogen retention observed at $29^{\circ} \mathrm{C}$ was in line with results previously obtained in juvenile sea bass (Person-Le Ruyet et al., 2004). To a lesser extent, protein retention was also decreased by n-3 HUFA deficiency. Overall protein retention was in the lower range of values reported for sea bass, 25 to $31 \%$ at $19-23^{\circ} \mathrm{C}$ (Hidalgo and Alliot, 1988; Ballestrazzi and Lanari, 1996). The low lipid content of the experimental diets $(16 \%)$ contributed to a rather low protein retention. The differences with usual values may also be explained by the high vegetal protein content in the experimental diets used in this study. However Kaushik et al. (2004) have observed similar protein efficiency ( 21 to $23 \%$ ) in sea bass fed diets with various replacement levels of protein from fish meal by plant protein sources.

Fish fatty acid composition was mainly affected by diet as summarised with distance coefficients (D). Diet influence has been reported in many experiments using different oil sources as fish composition tends to reflect diet composition (Hardy et al., 1987). However differences due to diets were lower in polar lipids than in total or neutral lipids, as fish tend to regulate their phospholipid (PL) composition (Sargent, 1976). The fatty acid profiles in PL correspond to the trends generally observed in various fish with high DHA, 16:0 and 18:1n-9 and with relatively high EPA and arachidonic acid contents compared to neutral lipids (NL) even when fish were fed a low HUFA diet. Such partial regulation of polar lipid fatty acids has been observed in juvenile sea bass fed $0.3 \% \mathrm{DM}$ HUFA (Skalli and Robin, 2004). FA composition in neutral lipid was very similar to total lipid within each treatment, as NL represented around $93 \%$ of total lipid. Temperature influenced more clearly polar lipid than neutral lipid fatty acid contents; HUFAs were 
lower at $29^{\circ} \mathrm{C}$ than at $22^{\circ} \mathrm{C}$. This thermal response is in agreement with general findings of a higher unsaturation in polar lipids at low temperatures as observed in salmonids or in freshwater species (Sargent, 1976; Hazel and Williams, 1990; Calabretti et al., 2003). Membrane adaptation to temperature is complex and many components (cholesterol, phospholipids classes) are involved (Hazel, 1993; Farkas et al., 2001).

The higher level of 18:3n-6 in fish fed LD compared to HD, mainly observed in polar lipids, suggests a desaturation of $18: 2 \mathrm{n}-6$ as the LD diet did not contain $18: 3 \mathrm{n}-6$. Similar bio-conversion capacity could be expected under HUFA deficiency as shown in several fish species, salmonids (Seiliez et al., 2001), gilthead sea bream (Seiliez et al., 2003) and sea bass (Skalli and Robin, 2004). The lower HUFA content in total lipids of LD-29 group compared to LD-22 group could be a result of a lower incorporation and bioconversion of polyunsaturated fatty acids at high than at low temperature. Such effects have been demonstrated by Tocher and Sargent (1990) using fish cells in culture. However, the observed difference was relatively low $(0.7 \%)$ and was not observed within fish fed $\mathrm{HD}$, a more appropriate essential dietary fatty acid level.

This study demonstrated that in juvenile sea bass having an initial high nutritional status, a deficiency in n-3 HUFA did not drastically impair their capacity to adapt to a higher temperature, $29^{\circ} \mathrm{C}$, at least for 3 months. However, the decrease in n-3 HUFA fish content induced by vegetal oil was more evident at the higher temperature. This result corresponds to an interaction between nutritional and environmental factors, affecting fish n-3 HUFA content. Further studies on the effects of such interactions on flesh quality should be developed, considering the potential effect of n-3 HUFA on consumer health. 


\section{Acknowledgements}

The authors are very grateful to C. Cahu and J. Zambonino-Infante for help in improving the manuscript and to L. Quéméner for advice in statistical analysis.

\section{References}

Ackman, R.G., 1995. Composition and nutritional value of fish and shellfish lipids.. In: Ruiter, A. (Ed.) Fish and Fisheries Products. Composition, Nutritive Properties and Stability. CAB International, Wallingford, UK pp. 117-156.

Alexis, M.N., 1997. Fish meal and fish oil replacers in Mediterranean marine fish diets. Cah. Options Mediterr. 22, 183-204.

Association of Official Analytical Chemists, 1984. Official Methods of Analysis of the Association of Analytical Chemists. Williams, S. (Ed.). AOAC, Arlington, VA, 1141 pp.

Ballestrazzi, R., Lanari, D., 1996. Growth, body composition and nutrient retention efficiency of growing sea bass (Dicentrarchus labrax L.) fed fish oil or fatty acid Ca salts. Aquaculture 139, 101-108.

Ballestrazzi, R., Lanari, D., D’Agaro, E., 1998. Performance, nutrient retention efficiency, total ammonia and reactive phosphorus excretion of growing European sea bass (Dicentrarchus labrax L.) as affected by diet processing and feeding level. Aquaculture $161,55-65$. 


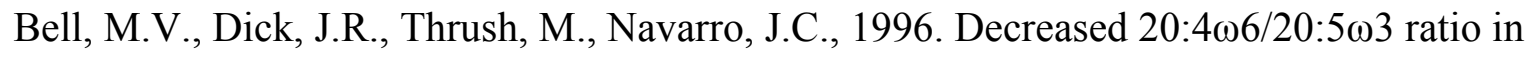
sperm from cultured sea bass Dicentrarchus labrax, broodstock compared to wild fish. Aquaculture 144, 189-199.

Bolin, D.W., King, R.P., Klosterman, E.W., 1952. A simplified method for the determination of chromic oxide $\left(\mathrm{Cr}_{2} \mathrm{O}_{3}\right)$ when used as an index substance. Science 116, 634-635.

Caballero, M.J., Obach, A., Rosenlund, G., Montero, D., Gisvold, M., Izquierdo, M.S., 2002. Impact of different dietary lipid sources on growth, lipid digestibility, tissue fatty acid composition and histology of rainbow trout, Oncorhynchus mykiss. Aquaculture $214,253-271$.

Calabretti, A., Cateni, F., Procida, G., Favretto, L.G., 2003. Influence of environmental temperature on composition of lipids in edible flesh of rainbow trout (Oncorhynchus mykiss). J. Sci. Food Agric. 83, 1493-1498.

Cho, C.Y., Slinger, S.J., Bayley, H.S., 1982. Bioenergetics of salmonid fishes: energy intake, expenditure and productivity. Comp. Biochem. Physiol. 73 (B), 25-41.

Claireaux, G., Lagardère J.P., 1999. Influence of temperature, oxygen and salinity on the metabolism of the European sea bass. Neth. J. Sea Res. 32, 135-152.

De la Higuera M., 2001. Effects of nutritional factors and feed characteristics on feed intake. In: Houlihan, D., Boujard, T., Jobling, M. (Eds.), Food Intake in Fish, Blackwell, Oxford, pp. 250-268.

Dosdat, A., Sevais, F., Métailler, R., Huelvan, C., Desbruyères, E., 1996. Comparison of nitrogenous losses in five teleost fish species. Aquaculture 141, 107-127. 
Farkas, T., Dey, I., Buda, C.S., Halver, J.E., 1994. Role of phospholipid molecular species in maintaining lipid membrane structure in response to temperature. Biophys. Chem. 50, 147-155.

Farkas, T., Fodor, E., Kitajka, K., Halver, J.E., 2001. Response of fish membranes to environmental temperature. Aquacult. Res. 32, 645-655.

Folch, J., Lees, M., Sloane-Stanley, G.H., 1957. A simple method for the isolation and purification of total lipids from animal tissues. J. Biol. Chem. 226, 497-509.

Grisdale-Helland, B., Ruyter, B., Rosenlund, G., Obach, A., Helland, S.J., Sandberg, M.G., Standal, H., Rosjo, C., 2002. Influence of high contents of dietary soybean oil on growth, feed utilization, tissue fatty acid composition, heart histology and standard oxygen consumption of Atlantic salmon (Salmo salar) raised at two temperatures. Aquaculture 207, 311-329.

Hardy, R.W., Scott, T.M., Harrell, L.W., 1987. Replacement of herring oil with menhaden oil, soybean oil, or tallow in the diets of Atlantic salmon raised in marine net-pens. Aquaculture 65, 267-277.

Hazel, J.R., 1993. Thermal biology. In: Evans, D.H. (Ed.) The Physiology of Fishes. CRC Press, Boca Raton, USA, pp. 427-468.

Hazel, J.R., Williams, E.E., 1990. The role of alterations in membrane lipid composition in enabling physiological adaptation of organisms to their physical environment. Prog. Lipid Res. 29, 167-227.

Hidalgo, F., Alliot, E., 1988. Influence of water temperature on protein requirement and protein utilization in juvenile sea bass, Dicentrarchus labrax. Aquaculture 72, 115-129. 
Ibeas, C., Izquierdo, M.S., Lorenzo, A., 1994. Effect of different levels of n-3 highly unsaturated fatty acids on growth and fatty acid composition of juvenile gilthead seabream (Sparus aurata). Aquaculture 127, 177-188.

Izquierdo, M.S., Obach, A., Arantzamendi, L., Montero, D., Robaina, L., Rosenlund, G., 2003. Dietary lipid sources for seabream and seabass: growth performance, tissue composition and flesh quality. Aquacult. Nutr. 9, 397-407.

Jobling, M., 1997. Temperature and growth: modulation of growth via temperature change. Soc. Exp. Biol. Sem. Ser. 61, 225-253.

Juaneda, P., Rocquelin, G., 1985. Rapid and convenient separation of phospholipids and non-phosphorus lipids from rat heart using silica cartridges. Lipids 20, 40-41.

Kalogeropoulos, N., Alexis, M.N., Henderson, R.J., 1992. Effects of dietary soybean and cod-liver oil levels on growth and body composition of gilthead sea bream (Sparus aurata). Aquaculture 104, 293-308.

Kaushik, S.J., Covès, D., Dutto, G., Blanc, D., 2004. Almost total replacement of fish meal by plant protein sources in the diet of a marine teleost, the European seabass, Dicentrarchus labrax. Aquaculture 230, 391-404.

Lanari, D., Poli, B.M., Ballestrazzi, R., Lupi, P., D’Agaro, E., Mecatti, M., 1999. The effects of dietary fat and NFE levels on growing European sea bass (Dicentrarchus labrax L.). Growth rate, body and fillet composition, carcass tarits and nutrient retention efficiency. Aquaculture 179, 351-364.

Lee, S.M., Lee, J.H., Kim, K.D., 2003. Effect of dietary essential fatty acids on growth, body composition and blood chemistry of juvenile starry flounder (Platichthys stellatus), Aquaculture 225, 269-281. 
Lemarié, G., Dosdat, A., Covès, D., Dutto, G., Gasset, E., Person-Le Ruyet, J., 2003. Effect of chronic ammonia exposure on growth of European seabass (Dicentrarchus labrax) juveniles. Aquaculture 229, 479-491.

Lodemel, J.B., Mayhew, T.M., Myklebust, R., Olsen, R.E., Espelid, S., Ringo, E., 2001. Effect of three dietary oils on disease susceptibility in Arctic charr (Salvelinus alpinus L.) during cohabitant challenge with Aeromonas salmonicida ssp. salmonicida. Aquacult. Res. 32, 935-946.

McIntire, C.D., Tinsley, I.J., Lowry, R.R., 1969. Fatty acids in lotic periphyton: another measure of community structure. J. Phycol. 5, 26-32.

McKenzie, D. J., 2001. Effects of dietary fatty acids on the respiratory and cardiovascular physiology of fish. Comp. Biochem. Physiol. 128 (A), 605-619.

Parpoura, A.C.R., Alexis, M.N., 2001. Effects of different dietary oils in sea bass (Dicentrarchus labrax) nutrition. Aquacult. Int. 9, 463-476.

Person-Le Ruyet, J., Pichavant, K., Vacher, C., Le bayon, N., Sévère, A., Boeuf, G., 2002. Effects of $\mathrm{O}_{2}$ supersaturation on metabolism and growth in juvenile turbot (Scophthalmus maximus L.). Aquaculture 205, 373-383.

Person-Le Ruyet, J., Mahé, K., Le Bayon, N., Le Delliou, H., 2004. Effects of temperature on growth and metabolism in a Mediterranean population of European sea bass, Dicentrarchus labrax. Aquaculture, 237, 269-280.

Pichavant, K., Person-Le Ruyet, J., Le Roux, A., Sévère, A., Le bayon, N., Boeuf, G., 2001. Comparative effects of long-term hypoxia on growth, feeding and oxygen consumption in juvenile turbot and European sea bass. J. Fish Biol. 59, 875-883. 
Regost, C., Arzel, J., Cardinal, M., Rosenlund, G., Kaushik, S.J., 2003. Total replacement of fish oil by soybean or linseed oil with a return to fish oil in turbot (Psetta maxima): 1 . Growth performance, flesh fatty acid profile, and lipid metabolism. Aquaculture 217, $465-482$.

Ringo, E., Lodemel, J.B., Myklebust, R., Jensen, L., Lund, V., Mayhew, T.M., Olsen, R.E., 2002. The effects of soybean, linseed and marine oils on aerobic gut microbiota of Arctic charr Salvelinus alpinus L. before and after challenge with Aeromonas salmonicida ssp. salmonicida. Aquacult. Res. 33, 591-606.

Rosenlund, G., Obach, A., Sandberg, M.G., Standal, H., Tveit, K., 2001. Effect of alternative lipid sources on long term growth performance and quality of Atlantic salmon (Salmo salar). Aquacult. Res. 32, 323-328.

Salte, R., Thomassen, M.S., Wold, K., 1988. Do high levels of dietary polyunsaturated fatty acids (EPA/DHA) prevent diseases associated with membrane degeneration in farmed Atlantic salmon at low water temperature? Bull. Eur. Assoc. Fish Pathol. 8, 63-66.

Sargent, J.R., 1976. The structure metabolism and function of lipids in marine organisms. Biochem. Biophys. Perspect. Mar. Biol. 3, 149-212.

Sargent, J.R., Tocher, D.R., Bell, J.G., 2002. The lipids. In: Halver, J.E, Hardy, R.W. (Eds.) Fish Nutrition. Academic Press, New York, pp. 181-257.

Seiliez, I., Panserat, S., Kaushik, S., Bergot, P., 2001. Cloning, tissue distribution and nutritional regulation of a $\Delta 6$-desaturase-like enzyme in rainbow trout. Comp. Biochem. Physiol. 130 (B), 83-93.

Seiliez, I., Panserat, S., Corraze, G., Kaushik, S., Bergot, P., 2003. Cloning and nutritional regulation of a $\Delta 6$-desaturase-like enzyme in the marine teleost gilthead seabream (Sparus aurata). Comp. Biochem. Physiol. 135 (B), 449-460. 
Skalli, A., Robin, J.H., 2004. Requirement in n-3 long chain polyunsaturated fatty acids for European sea bass juveniles: growth and fatty acid composition. Aquaculture, 240, 399415.

Staurnes, M., Rainuzzo, J.R., Sigholt, T., Joergensen, L., 1994. Acclimation of Atlantic cod (Gadus morhua) to cold water. Stress response, osmoregulation, gill lipid composition and gill Na-K-ATPase activity. Comp. Biochem. Physiol. 109 (A), 413-421.

Tocher, D.R., 2003. Metabolism and functions of lipids and fatty acids in teleost fish. Rev. Fish. Sci. 11, 107-184.

Tocher, D.R., Sargent, J.R., 1990. Effect of temperature on the incorporation into phospholipid classes and metabolism via desaturation and elongation of n-3 and n-6 polyunsaturated fatty acids in fish cells in culture. Lipids 25, 435-442.

Ventrella, V., Pagliarani, A., Pirini, M., Trigari, G., Trombetti, F., Borgatti, A.R., 1993. Lipid composition and microsomal ATPase activities in gills and kidneys of warm and cold acclimated sea bass (Dicentrarchus labrax L.). Fish Physiol. Biochem. 12, 293-304. Yildiz, M., Sener, E., 1997. Effect of dietary supplementation with soybean oil, sunflower oil or fish oil on the growth of seabass (Dicentrarchus labrax L. 1758). Cah. Options Mediterr. 22, 225-233. 